\title{
Challenges of a novel range: Water balance, stress, and immunity in an invasive toad
}

\author{
Adriana Maria Giorgi Barsotti ${ }^{\mathrm{a}, \mathrm{b}, \text {, }}$, Carla Bonetti Madelaire ${ }^{\mathrm{a}, \mathrm{b}}$, Carla Wagener ${ }^{\mathrm{b}}$, Braz Titon $\mathrm{Jr}^{\mathrm{a}}$, \\ John Measey $^{\mathrm{b}}$, Fernando Ribeiro Gomes ${ }^{\mathrm{a}}$ \\ a Instituto de Biociências, Departamento de Fisiologia, USP - Universidade de São Paulo, Rua do Matão, trav 14 n 321, Cidade Universitária, São Paulo, SP 05508-090, \\ Brazil \\ ${ }^{\mathrm{b}}$ Centre for Invasion Biology, Department of Botany and Zoology, Stellenbosch University, Stellenbosch, South Africa
}

\section{A R T I C L E I N F O}

\section{Keywords:}

Invasive species

Dehydration

Corticosterone

Immunocompetence

\begin{abstract}
A B S T R A C T
Species introduced by human activities can alter the normal functioning of ecosystems promoting negative impacts on native biodiversity, as they can rapidly expand their population size, demonstrating phenotypic plasticity and possible adaptive capacity to novel environments. Twenty years ago, the guttural toad, Sclerophrys gutturalis, was introduced to a peri-urban area of Cape Town, with cooler and drier climatic characteristics than its native source population, Durban, South Africa. Our goal was to understand the phenotypic changes, in terms of physiology and immunity, of populations in native and novel environments. We evaluated body index (BI), field hydration level, plasma corticosterone levels (CORT), proportion of neutrophils: lymphocytes (N: L), plasma bacterial killing ability (BKA), and hematocrit (HTC) in the field, and after standardized stressors (dehydration and movement restriction) in males from the native and invasive populations. Toads from the invasive population presented lower BI and tended to show a lower field hydration state, which is consistent with living in the drier environmental conditions of Cape Town. Additionally, invasive toads also showed higher BKA and N:L ratio under field conditions. After exposure to stressors, invasive animals presented higher BKA than the natives. Individuals from both populations showed increased CORT after dehydration, an intense stressor for these animals. The highest BKA and N:L ratio in the field and after submission to stressors in the laboratory shows that the invasive population has a phenotype that might increase their fitness, leading to adaptive responses in the novel environment and, thus, favoring successful dispersion and population increase.
\end{abstract}

\section{Introduction}

Species introduced through human activities are present in many ecosystems and some of these species may become invasive and rapidly expand their populations (Torchin et al., 2003; Seebacher and Franklin, 2011). A high invasive potential is mainly due to their ability to produce integrated phenotypes reconciling pressures from many selective agents allowing for greater expansion efficiency (Reznick and Ghalambor, 2001; Lee, 2002; Sax et al., 2007; Jessop et al., 2013). Due to this rapid evolution and population increase, invasive species are currently recognized as one of the main threats to vertebrate populations (Mooney and Hobbs, 2000; Strauss et al., 2006) as they exploit the same resources used by local populations (Altieri et al., 2010), thus causing biodiversity losses (Pimentel, 2014). For this reason, invasive species provide an excellent model for investigating how organisms mitigate the various challenges associated with rapid environmental change.

To understand how these species adapt to environmental changes in novel habitats, it is necessary to integrate information on physiological mechanisms and processes that regulate and integrate the various phenotypic characteristics optimizing the fitness of individuals (Wingfield, 2008; Chown et al., 2010; Martin et al., 2011; Cohen et al., 2012; Jessop et al., 2013). Some environmental challenges, as potential stressors, can activate the hypothalamic-pituitary-adrenal/interrenal (HPA/I) axis in vertebrates, resulting increased levels of plasma glucocorticoids (GCs), such as corticosterone (CORT). CORT is a metabolic hormone, and its secretion is increased in response to higher energy demands associated with environmental challenges, such as limited resources and/or divergent climatic conditions (Bonier et al., 2009).

\footnotetext{
* Corresponding author at: Instituto de Biociências, Departamento de Fisiologia, USP - Universidade de São Paulo, Rua do Matão, trav 14 n 321, Cidade Universitária, São Paulo, SP 05508-090, Brazil

E-mail address: adriana33@gmail.com (A.M.G. Barsotti).
} 
Additionally, it can modulate several functions, such as reproduction, behavior, immunocompetence, and growth (Sapolsky et al., 2000; Dhabhar, 2014). The acute activation of the HPA/I axis results in an integrative and adaptive response to short-term stressors (Wingfield et al., 1997; Sapolsky et al., 2000; Romero and Wingfield, 2001; Sapolsky, 2002). For example, GCs are known to be immunomodulatory hormones and have bimodal effects on the immune system. Short-term increased GC secretion in response to acute stressors is associated with imunnoenhancing effects, including increased presentation of antigens, effector cell function and production of antibodies and cytokines (Dhabhar and McEwen, 1996; Dhabhar, 1998; Dhabhar and McEwen, 1997; Madelaire et al., 2017). These immunoenhancing effects increase immune surveillance in the face of stressors, preparing the immune system for a rapid response to an immune challenge, such as injury or infection (Dhabhar et al., 1994, 1995, 1996; Dhabhar and McEwen, 1996; Dhabhar, 1998). On the other hand, long-term increase of GC secretion in response to chronic stressors is usually associated with immunosuppressive effects (Dhabhar and McEwen, 1997; Dhabhar, 2014; Titon et al., 2018), such as suppression of maturation, differentiation and proliferation of immune cells (Sterberg, 2006; Martin, 2009) in addition to triggering apoptosis in T and B cells (Sapolsky et al., 2000) and reduction of anti-inflammatory effects (Dhabhar, 2014). Additionally, exposure to chronic stressors can alter the ability of the HPI axis to respond to acute secondary stressors (Rich and Romero, 2005). In the wild, animals may be subjected to chronic and/or intense acute stressors, and additional stressors may lead to allostatic overload, affecting their ability to mount a rapid response and compromising their survival (Romero and Wingfield, 2015).

When compared with other tetrapods, amphibians have comparatively higher rates of transcutaneous evaporation (Toledo and Jared, 1993), and one of the challenges in a new environment may be the maintenance of adequate hydration levels. Dehydration affects locomotor performance and its underlying physiological determinants (e.g. Vimercati et al., 2018), which may impair ecologically relevant behaviors such as breeding, foraging, and escape from predators (Moore and Gatten Jr, 1989; Titon Jr and Gomes, 2017). Accordingly, dehydration represents a potent stressor for toads, activating the HPI axis and increasing CORT secretion (Barsotti et al., 2019), which may affect immune function, as observed in other ectothermic vertebrates (Moeller et al., 2013, 2017). Despite the general physiological characteristics assumed in the literature as potentially restrictive to the spread of originally mesic amphibians to more xeric novel environments, recent studies have described fast and integrated behavioral and physiological adaptations of invasive amphibians to unfavorable drier conditions (Tingley et al., 2012; Kosmala et al., 2017, 2020; Roznik et al., 2018). Cane toads (Rhinella marina) from the invasion front in the Australian desert, for example, show greater tolerance to dehydration and better locomotor performance when dehydrated than their native conspecifics (Kosmala et al., 2017). In addition, cane toads from drier areas in Australia show higher rates of water uptake than those from more mesic areas (Tingley et al., 2012). Moreover, the behavioral flexibility associated with shelter selection and adjustments of daily movement rates according to ambient moisture has been key for invasive cane toads to successfully colonize arid zones in Australia (Tingley and Shine, 2011).

Likewise, an invasive population of guttural toads (Sclerophrys gutturalis) has recently established (2000) in Cape Town, in a climate significantly drier and colder than that of the native source area of Durban, South Africa (Telford et al., 2019; Measey et al., 2020). Previous studies have shown that these invasive toads outperformed those from the native range in locomotor trials when dehydrated and were more efficient in minimizing rates of water loss through postural adjustments (Vimercati et al., 2018, 2019). However, the interaction between response to stress and functions modulated by this response, such as immunocompetence, has not yet been explored in this invasive population of the guttural toad. Despite an eradication program, the species is still spreading across the invaded area, in a small peri-urban area of Cape
Town (Measey et al., 2017; Davies et al., 2020). Therefore, it is important to study the adjustments in the physiological characteristics and life history of invasive guttural toads, in order to predict its potential for propagation within Cape Town. In addition, by comparing the invasive population with the native population, we can clarify information about the possible phenomena that may increase the fitness of this species in the invaded area.

In the present study, we aim to compare the stress response and its effects in immunocompetence of native and invasive populations of $S$. gutturalis. We hypothesize that invasive individuals of $S$. gutturalis are under chronic stress in Cape Town's drier environment, and thus show lower immunocompetence and a reduced ability to respond to an acute stressor when compared to individuals from native populations in the more humid region of Durban. To test our hypothesis, we compared blood samples collected in the field and after experimental manipulation in the laboratory of male individuals from invasive and native populations. The experiment consisted of dehydrating animals by $10 \%$ or $20 \%$, followed by movement restriction for $24 \mathrm{~h}$. Blood samples were collected before and after dehydration, and after restriction. We measured body index and hydration state in the field, hematocrit (HTC) as an estimate of hydration levels, corticosterone plasma levels (CORT) and neutrophil: lymphocyte (N:L) ratio as estimates of stress, and bacterial killing ability (BKA) as an estimate of immunocompetence. According to our hypotheses and experimental design employed we predicted that: 1 ) individuals of $S$. gutturalis from the invasive population will display higher CORT and N:L ratio, lower hydration state and lower BKA in the field when compared to the native population; 2) after submission to dehydration and movement restriction stress, toads from both populations will present increased CORT and N:L ratio, and lower BKA; 3) individuals from the native population will have higher CORT, $\mathrm{N}: \mathrm{L}$ ratio and BKA after both dehydration and movement restriction.

\section{Data collection}

\subsection{Study species, collection localities, and maintenance in captivity}

Male Sclerophrys gutturalis were collected in Cape Town (87 $\mathrm{m}$ a.s.1., $34^{\circ} 01^{\prime} \mathrm{S}, 18^{\circ} 25^{\prime} \mathrm{E}$ ) and Durban (75 m a.s.1., $29^{\circ} 47^{\prime} \mathrm{S}, 31^{\circ} 01^{\prime} \mathrm{E}$ ), corresponding to invasive and native populations, respectively (see Telford et al., 2019).

In Cape Town, 25 invasive individuals were collected in the periurban Constantia region with prior permission from CapeNature (Permit No.: CN44-31-7259) and with the assistance of the Nature Conservation Corporation. The collections were carried out in private residences, where toads were found close to or immersed in bodies of water (e.g. fountains, ponds, and swimming pools: see Vimercati et al., 2017), between 17 and 27 January 2019 [Average temperature, dew point, and relative humidity for the collection days: $20.2{ }^{\circ} \mathrm{C}, 13.5^{\circ} \mathrm{C}$ and $65.8 \%$, respectively (Source: Weather Underground website, available at https://www.wunderground.com/dashboard/pws/IWCAPECO2)].

A total of 20 male Sclerophrys gutturalis individuals from the native population were collected in a similar peri-urban area of Durban North with prior permission from KZN Wildlife (Permit No.: OP 4353/2018), between 16 and 23 February 2019 [Average temperature, dew point, and relative humidity for the collection days: $25.5{ }^{\circ} \mathrm{C}, 21.8{ }^{\circ} \mathrm{C}$ and $81.1 \%$, respectively (Source: Weather Underground website, available at https://www.wunderground.com/dashboard/pws/IKWAZULU12)]. The collections were carried out on residential streets, some private residences, and a golf course.

The animals were collected at both sites during the reproductive period of the species (Vimercati et al., 2019). They were located by visual inspection, captured by hand and a blood sample was collected in the field (details below). Subsequently, animals were weighed using a portable balance ( $\pm 0.01 \mathrm{~g}$, WTB 2000, Radwag, Radom, Poland) and placed individually in pots with water overnight to rehydrate. After rehydration, individuals had their bladders emptied by pressure in the 
ventrum (Titon Jr and Gomes, 2017), and were then weighed again. Body mass of $100 \%$ hydrated individuals with empty bladders were considered as the standard mass (Ruibal, 1962; Titon Jr and Gomes, 2017). Field hydration state was calculated as the field mass divided by the standard mass after rehydration (Preest and Pough, 1989; Preest et al., 1992; Tracy et al., 2014). Animals of both populations were brought to Stellenbosch University and kept individually in plastic containers $(43.0(\mathrm{~W}) \times 28.5(\mathrm{~L}) \times 26.5(\mathrm{H}) \mathrm{cm})$ with foliage, and water and crickets (Acheta domesticus) were provided ad libitum. The containers and water were checked daily, and the boxes cleaned when needed. Animals were kept in a climatic chamber with constant temperature $\left(24^{\circ} \mathrm{C} \pm 1{ }^{\circ} \mathrm{C}\right)$, relative humidity $(40 \% \pm 1 \%)$ and $13 \mathrm{~L}: 11 \mathrm{D}$ light regime. In order to allow for the recovery of blood volume, all individuals were kept in these conditions for at least one week before being submitted to stress by dehydration and movement restriction. After the experiments were finished, we measured animals' snout-vent length (SVL) in order to calculate the body index (BI), which was calculated as unstandardized residuals of a linear regression of standard mass as a function of SVL.

\subsection{Collection of blood samples}

Blood collection was performed by cardiac puncture with $1 \mathrm{~mL}$ syringes and previously heparinized $26 \mathrm{Gx} 1 / 2^{\prime \prime}$ needles. Only blood samples collected within $3 \mathrm{~min}$ after the capture of the animal were considered in order to avoid possible influences of capture and manipulation (Romero and Reed, 2005; Tylan et al., 2020). The individuals were sampled once at the time of collection and twice in the experiment, for each sample, approximately $100 \mu \mathrm{L}$ of blood was drawn. The minimal interval between the date of collection and the experiment in the laboratory was 1 week, enough time for the animals to recover the blood, since amphibians, especially terrestrial ones, have a high capacity to regulate blood volume in the face of dehydration and hemorrhage (Hillman, 2018). These samples were used to evaluate the corticosterone plasma levels (CORT), neutrophil:lymphocyte ratio (N: L ratio), bacterial killing ability (BKA) and hematocrit (HTC) collected in the field and after subjection to stressors in the laboratory.

All blood samples were identified and kept on ice until divided into three aliquots. One of these aliquots was used to mount two blood smear slides for leukocyte profile $(\approx 4 \mu \mathrm{L})$, another for hematocrit $(\mathrm{HTC})(\approx 5$ $\mu \mathrm{L})$ measurement and a third one was transferred to Eppendorf tubes and centrifuged ( $4 \mathrm{~min}$ at $604 \mathrm{~g}$ ) for plasma separation. Plasma samples were kept on ice until transferred to the $-80{ }^{\circ} \mathrm{C}$ freezer the same night. 5-10 $\mu \mathrm{L}$ of plasma were used for hormonal and BKA analysis, respectively.

\subsection{Dehydration and movement restriction}

The animals were randomly divided into 3 groups with different levels of hydration: control (100\% hydrated), $10 \%$ and $20 \%$ dehydration groups. An ANOVA test with Bonferroni adjustment was performed to assess whether there was a statistical difference between groups with respect to mass. The test showed that there was no difference in mass between groups for both populations (native population: $P=0.441 ; F=$ 0.850 ; invasive population: $P=0.665 ; F=0.281$ ). The animals in the control group remained with access to water throughout the period of data collection. The toads from the $10 \%$ and $20 \%$ dehydration groups were weighed in the laboratory again when fully hydrated and with empty bladders. They were then deprived of food two days before the experiment and of access to water the day before the experiment until the time of blood sampling, which allowed for natural evaporative water loss. To increase the rate of water loss for the animals from the $20 \%$ dehydration group, we replaced the plastic top of the box with a mesh. Both groups lost the desired mass in a period of $24 \mathrm{~h}$. The next morning the toads were weighed to check if they reached the mass corresponding to the level of dehydration desired and then had a blood sample collected. If the toads had not reached the desired mass, we would place them closer to the fan to dehydrate and and reach the desired mass more quickly. Toads had their body mass reduced through cutaneous water loss by $10 \%$ or $20 \%$ of the initial body mass; for example, a toad with an initial mass of $100 \mathrm{~g}$ achieves a dehydration percentage of $10 \%$ or $20 \%$ with a mass of $90 \mathrm{~g}$ and $80 \mathrm{~g}$, respectively. Once reaching the target mass, individuals had samples of blood collected. Toads from the control group were handled and weighed as those from the $10 \%$ and $20 \%$ dehydration groups in order to control for handling stress and, later, they were submitted to movement restriction stress.

To perform the movement restriction stress test, toads from all groups were placed in wet cloth bags inside their individual maintenance containers and remained in these conditions for a period of $24 \mathrm{~h}$, following Assis et al. (2015). After this period, blood samples were collected to evaluate the variables: BKA, N:L ratio, CORT and HTC.

The collections and the laboratory experiment were authorized by the Research Ethics Committee: Animal Care and Use of Stellenbosch University (reference number \#ACU-2019-8839).

\subsection{Bacterial Killing Ability (BKA)}

To perform this test, we followed the protocol of Assis et al. (2013). Briefly, plasma samples were diluted in amphibian Ringer's solution (10 $\mu \mathrm{L}$ plasma, $190 \mu \mathrm{L}$ Ringer's) and then mixed with a $10 \mu \mathrm{L}$ Aeromonas hydrophila working solution $\left(1 \times 10^{5}\right.$ microorganisms $\mathrm{mL}^{-1}$, A. hydrophila, IOC/ FDA 110- 36). Positive controls consisted of $10 \mu \mathrm{L}$ bacteria working solution in $200 \mu \mathrm{L}$ Ringer's solution, and negative controls contained $210 \mu \mathrm{L}$ Ringer's solution. Both controls and samples were incubated at $37{ }^{\circ} \mathrm{C}$, optimal temperature for bacterial growth, for 60 $\min$. We chose to use the optimal growth temperature of $A$. hydrophila instead of an ecologically relevant temperature for $S$. gutturalis because there is interspecific variation in temperatures that maximize BKA in bufonids (Moretti et al., 2019), and we did not access the thermal sensitivity curve of BKA for $S$. gutturalis previously to this study. In addition, most studies involving interaction between plasma and bacteria use the optimal growth temperature for the bacteria and this allows us to make comparisons with other studies. After incubation, $500 \mu \mathrm{L}$ of TSB (Tryptic Soy Broth) was added to each sample, vortexed and pipetted (300 $\mu \mathrm{L}$ from each sample), in duplicate, into a 96-well plate. The microplate was incubated at $37^{\circ} \mathrm{C}$ for $1 \mathrm{~h}$, and thereafter the optical density of the samples was measured hourly in a plate spectrophotometer (Thermo, model Multiskan EX) at a wavelength of $595 \mathrm{~nm}$, totaling four readings. The plasma BKA was evaluated at the beginning of the bacterial exponential growth phase and calculated according to the formula: 1 - [optical density of sample/ optical density of positive control (Assis et al., 2013)]. The optical density of the samples is the average of the two duplicates. The result of this division is the proportion of microorganisms that the toads' plasma was able to kill compared to the proportion of microorganisms in the positive control.

\subsection{Leukocyte profile}

One drop of blood $(\approx 2 \mu \mathrm{L})$ was used to make two blood smear slides. One of them was stained with Giemsa's solution (10\%) to perform differential counting leukocyte types. In an optical microscope with a magnification of $100 \times$, one hundred leukocytes were counted on each slide and classified into neutrophils, lymphocytes, eosinophils, basophils and monocytes for each animal (Campbell, 2012).

\subsection{Hormone dosage}

Steroid hormones were initially extracted with ether according to Assis et al. (2015, 2019). Plasma CORT levels were determined using EIA kits (CORT number 501320; Cayman Chemical), according to the manufacturer's instructions and previous studies conducted with toads from the genus Rhinella (Assis et al., 2019; Titon et al., 2018; Madelaire 
et al., 2019; Barsotti et al., 2019). The intra- and inter-assay variation were $11.22 \%$ and $3.35 \%$, respectively. The sensitivity of the assays, calculated as $80 \% \mathrm{~B} / \mathrm{B} 0$ curve value, was $22.84 \mathrm{pg}$.

Validation of the use of the corticosterone assay kit from Cayman Chemicals (cat number 501320; Cayman Chemical, Ann Arbor, Michigan) for $S$. gutturalis was conducted with a parallelism test, including baseline. Pooled plasma samples leftover ( $25 \mu \mathrm{L}$ of 10 subjects) were initially extracted with $5 \mathrm{~mL}$ of ethyl ether and followed the same procedures mentioned above (according to Assis et al., 2015, 2019). At the end, these pooled samples were resuspended and diluted in EIA buffer. The top standard of the corticosterone kit and the pooled plasma samples were used for a serial dilution (neat, 1:2, 1:4; 1:8, 1:16, 1:32, 1:64 and 1:128) and assayed on the same plate. The standard and sample corticosterone concentration were plotted as a function of Binding/Total Binding, and the $50 \%$ binding point was considered indicative of the best dilution factor to run the samples. The standard and sample curves were parallel, not crossing each other (Fig. 1- supp. file), corroborating the functionality of the assay for guttural toads. The best dilution factor for baseline pooled plasma samples from $S$. gutturalis corresponds to 1:2 (Fig. 1- supp. file).

\subsection{Hematocrit (HTC)}

The HTC was measured shortly after blood samples were collected and calculated as the ratio of blood cells to total blood volume after centrifugation of blood within a microhematocrit tube (4 $\mathrm{min}$ at $218 \mathrm{~g}$ ).

\subsection{Statistical analysis}

Data were initially submitted to descriptive statistics and the Shapiro-Wilk normality test. HTC $\left(\log _{10+1}\right)$, BKA (ACOS), N:L ratio (square root) and CORT $\left(\log _{10+1}\right)$ were transformed to adjust to the premise for parametric tests. Differences in field variables between invasive and native populations were verified by $t$-tests. A set of mixed ANCOVAs were performed to evaluate possible effects of body index as a covariate for the variables of the experiment. The body index was calculated as unstandardized residuals of a linear regression of standard mass as a function of snout-vent-length and were considered as a proxy of body condition to both populations.

In these ANCOVAs, physiological variables were considered as dependent variables, dehydration (control, 10\% dehydration and $20 \%$ dehydration) and population (native and invasive) were considered as a between subject factor and restraint was considered as a within subject factor following a full factorial model. When the covariate effect was not

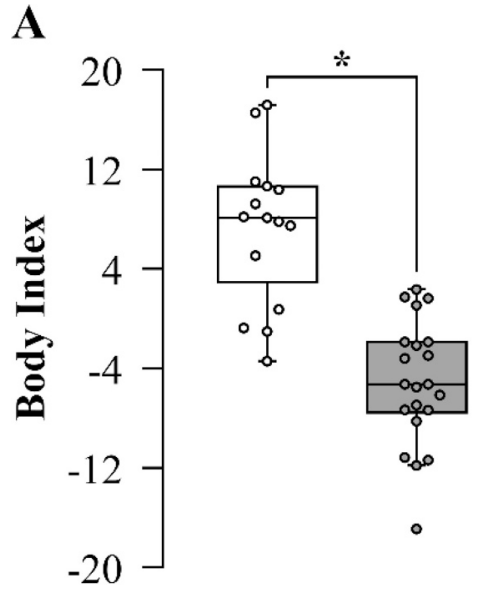

Native Invasive
B

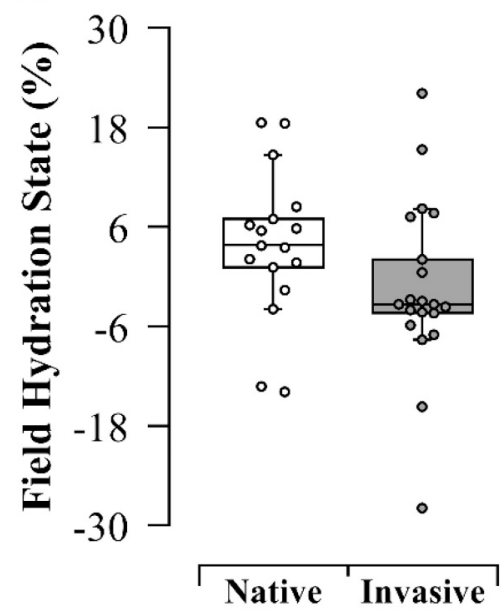

D

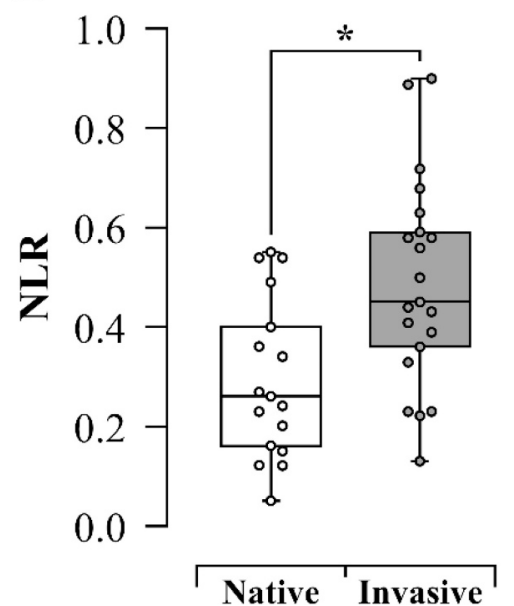

E
C

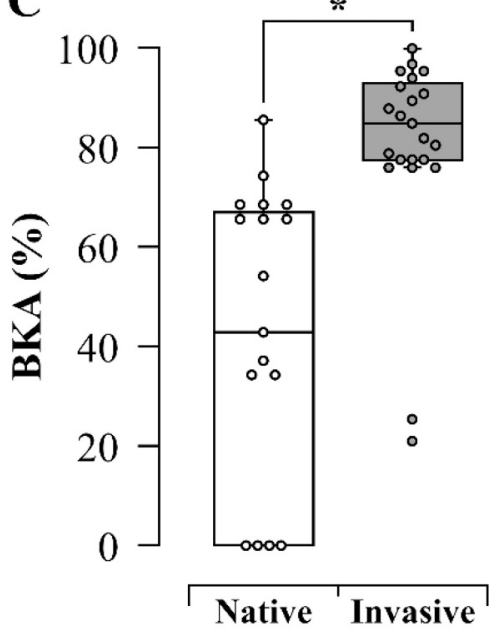

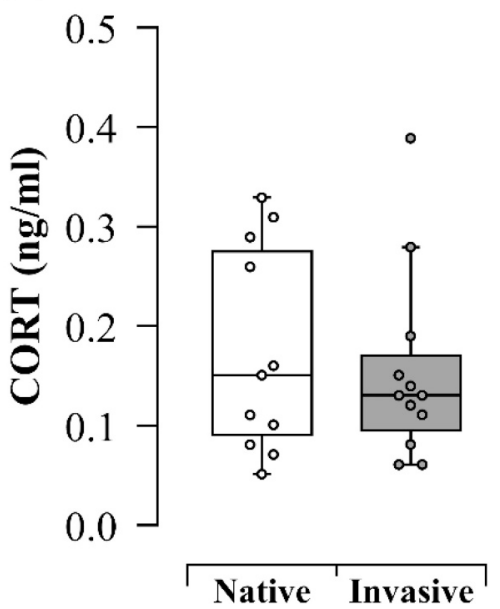

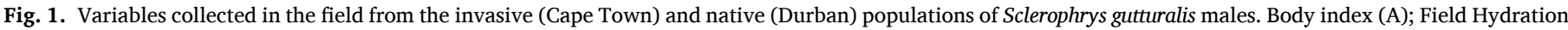

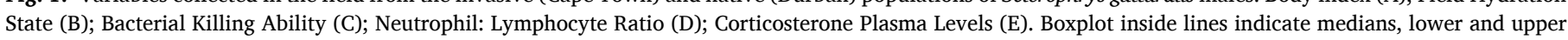

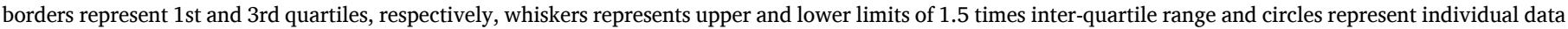
points. Asterisk $\left.{ }^{*}\right)$ represents mean multiple comparisons with Bonferroni adjustment significant differences $(P \leq 0.05)$. 
present, the covariate was eliminated from the model. The analysis was followed by a means comparison test, using the Bonferroni adjustment. Statistical analyses were performed in SPSS 22 for Windows (IBM Corp., Armonk, NY).

\section{Results}

\subsection{Comparison between invasive and native population of baseline} samples

Individuals from Cape Town (invasive population) and Durban (native population) differed in baseline variables of field mass, standard body mass, body index, BKA and N:L ratio (Table 1 ). The field mass recorded at the time of collection $\left(t_{41}=-3.859, P<0.001\right)$ and the body condition $\left(t_{34}=-6.632 P<0.001\right.$, Fig. $\left.1 \mathrm{~A}\right)$ were higher for the native population compared to the invasive population. In addition, the standard body mass was higher in individuals from the native population $\left(t_{39}=-4.767, P<0.001\right)$. Although not significant, there was a tendency of higher field hydration state for individuals from the native population $\left(t_{39}=-1.795, P=0.080\right.$; Fig. $1 \mathrm{~B}$ ). Individuals from the native population showed lower BKA and $\mathrm{N}$ : $\mathrm{L}$ compared to those from the invasive population $\left(t_{40}=-5.525, P<0.001, t_{39}=2.316, P=\right.$ 0.026; Figs. $1 \mathrm{C}$ and D, respectively). CORT did not differ between populations $\left(t_{20.182}=-0.811, P=0.427\right.$, Fig. $\left.1 \mathrm{E}\right)$.

Table 1

Descriptive statistics and statistical analysis ( $t$-test) comparing field data (body mass, rehydrated mass, dehydration level in field, snout-vent length, body index, bacterial killing ability, neutrophil: lymphocyte ratio and corticosterone plasma levels) of invasive and native Sclerophrys gutturalis populations. Due to technical issues, not all variables were measured for all individuals.

\begin{tabular}{|c|c|c|c|c|c|c|}
\hline Variables & Population & $\mathrm{N}$ & Mean \pm SD & $\mathrm{t}$ & DF & $P$-value \\
\hline \multirow[t]{2}{*}{ Field Mass (g) } & Invasive & 23 & $\begin{array}{l}31.810 \pm \\
9.029\end{array}$ & -3.859 & 41 & $<0.001$ \\
\hline & Native & 20 & $\begin{array}{l}43.983 \pm \\
11.633\end{array}$ & & & \\
\hline \multirow[t]{2}{*}{$\begin{array}{l}\text { Standard Body } \\
\text { Mass (g) }\end{array}$} & Invasive & 21 & $\begin{array}{l}30.800 \pm \\
8.904\end{array}$ & -4.767 & 39 & $<0.001$ \\
\hline & Native & 20 & $\begin{array}{l}45.606 \pm \\
10.928\end{array}$ & & & \\
\hline \multirow[t]{2}{*}{$\begin{array}{l}\text { Field Hydration } \\
\text { State (\%) }\end{array}$} & Invasive & 21 & $\begin{array}{l}-1.606 \pm \\
10.365\end{array}$ & -1.795 & 39 & 0.080 \\
\hline & Native & 20 & $\begin{array}{l}3.815 \pm \\
8.868\end{array}$ & & & \\
\hline \multirow[t]{2}{*}{ SVL (mm) } & Invasive & 25 & $\begin{array}{l}73.336 \pm \\
7.296\end{array}$ & -0.389 & 38 & 0.699 \\
\hline & Native & 15 & $\begin{array}{l}74.267 \pm \\
7.363\end{array}$ & & & \\
\hline \multirow[t]{2}{*}{$\begin{array}{l}\text { Body Condition } \\
\text { (g.mm-3) }\end{array}$} & Invasive & 21 & $\begin{array}{l}-5.162 \pm \\
5.075\end{array}$ & -6.632 & 34 & $<0.001$ \\
\hline & Native & 15 & $\begin{array}{l}7.227 \pm \\
6.110\end{array}$ & & & \\
\hline \multirow[t]{2}{*}{ BKA Field (\%) } & Invasive & 23 & $\begin{array}{l}80.855 \pm \\
19.818\end{array}$ & -5.525 & 40 & $<0.001$ \\
\hline & Native & 19 & $\begin{array}{l}40.300 \pm \\
31.252\end{array}$ & & & \\
\hline \multirow[t]{2}{*}{ N:L Ratio Field } & Invasive & 25 & $\begin{array}{l}0.488 \pm \\
0.208\end{array}$ & 2.316 & 39 & 0.026 \\
\hline & Native & 20 & $\begin{array}{l}0.345 \pm \\
0.201\end{array}$ & & & \\
\hline \multirow[t]{2}{*}{ CORT (ng/mL) } & Invasive & 12 & $\begin{array}{l}0.154 \pm \\
0.095\end{array}$ & -0.780 & 22 & 0.444 \\
\hline & Native & 13 & $\begin{array}{l}0.159 \pm \\
0.101\end{array}$ & & & \\
\hline
\end{tabular}

SD: Standard deviation; DF: degrees of freedom; SVL: Snout-Vent Length; BKA: Bacterial Killing Ability; N:L Ratio: Neutrophil: Lymphocyte Ratio; CORT: Corticosterone plasma levels.

\subsection{Experimental dehydration and movement restriction: comparison} between invasive and native populations

Mixed ANOVA shows significant difference between populations for HTC and BKA $\left(F_{1,29}=8.018, P=0.008, F_{1,34}=142.202, P<0.001\right.$, respectively, Tables 2 and 3). N:L ratio was affected by restraint, dehydration and an interaction between populations and restraint $\left(F_{1}\right.$, $33=87.737, P<0.001, F_{2,33}=4.739, P=0.016, F_{1,33}=10.117, P=$ 0.003 , respectively, Table 3 ). Individuals from the native population showed lower BKA than individuals from the invasive population both after dehydration and after movement restriction (control group: $P<$ $0.001,10 \%$ dehydration group: $P<0.001,20 \%$ dehydration group after dehydration: $P=0.010,20 \%$ dehydration group after restriction of movement: $P<0.001$, Fig. 2). In addition, within the invasive population, toads dehydrated by $20 \%$ increased BKA compared to the control group ( $P=0.034$, Fig. 2 ). The populations had no changes in the $\mathrm{N}$ : $\mathrm{L}$ ratio after dehydration. Nonetheless, individuals from the invasive population showed increased $\mathrm{N}: \mathrm{L}$ ratio after movement restriction in control, $10 \%$ and $20 \%$ dehydration groups $(P<0.001$; Fig. 3). Individuals from the native population also showed higher $\mathrm{N}$ :L ratio after movement restriction in control and $10 \%$ dehydration groups $(P=$ $0.001 ; P=0.012$, respectively), but not in the $20 \%$ dehydration group $(P=0.417$, Fig. 3).

Toads from native and invasive populations did not differ in CORT in response to the treatments. CORT was higher in invasive toads dehydrated by $10 \%$ and $20 \%$ when compared with the control group $(P=$ 0.002 and $P=0.007$, respectively, Fig. 4). Invasive toads dehydrated by $10 \%$ presented higher CORT than those from the control group after movement restriction ( $P=0.019$, Fig. 4). In parallel, CORT was higher in native toads dehydrated by $20 \%$ when compared to the control group $(P=0.017$, Fig. 4). Invasive and native toads showed lower CORT after movement restriction when compared to those measured after dehydration at $20 \%(P=0.005$ and $P=0.022$, respectively, Fig. 4$)$. The results also showed an interaction between restriction and group for CORT ( $P=0.003$, Table 3 ).

Native toads showed higher HTC than invasive toads after movement restriction in control and $20 \%$ dehydration groups $(P=0.030$ and $P=$ 0.046, respectively; Fig. 5).

\section{Discussion}

Guttural toads, Sclerophrys gutturalis, from the invasive population had a lower body index and standard body mass, and higher BKA and N: $\mathrm{L}$ ratio, compared to individuals from the native population under field conditions. These results are consistent with previous studies showing that the challenges of invasion can directly impact body condition of invasive animals (Brown et al., 2011; Vimercati et al., 2019). Cape Town is characterized by a Mediterranean climate with limited water availability in summer, compared to the native region of these invasive guttural toads, which could reduce the amount and diversity of arthropod prey for anurans (Vimercati et al., 2019). They are probably also restricted in hours of foraging activity, given the increased need to remain longer in microenvironments in contact with water. Additionally, the invasive population of $S$. gutturalis had lower field body mass and tended to show a lower field hydration state than those from the native range. Vimercati et al. (2018) compared the same two populations of $S$. gutturalis and found similar results, along with a positive relationship between hydration level and relative humidity. These results in conjunction suggest that these invasive toads live under stressful conditions of higher dehydration potential.

The invasive population of $S$. gutturalis had higher BKA and N: L ratio compare to the native population. Some studies have shown a lower immune response of toads on the invasion front compared to longer established populations (Brown et al., 2007; Brown and Shine, 2014; Llewellyn et al., 2012). However, the literature has shown diverse and contradictory data related to immunocompetence of invasive organisms. 
Table 2

Descriptive statistics of hematocrit, bacterial killing ability, neutrophil: lymphocyte ratio and corticosterone plasma levels analyzed after the experiment of dehydration stress and movement restriction for Sclerophrys gutturalis invasive and native populations.

\begin{tabular}{|c|c|c|c|c|c|c|}
\hline Variable & Restriction & Population & Group & $\mathrm{N}$ & Mean & SD \\
\hline \multirow[t]{12}{*}{ HTC (\%) } & \multirow[t]{6}{*}{ Pre } & \multirow[t]{3}{*}{ Invasive } & Control & 6 & 19.028 & 9.402 \\
\hline & & & $\begin{array}{l}\text { Dehydration } \\
10 \%\end{array}$ & 7 & 27.701 & 7.443 \\
\hline & & & $\begin{array}{l}\text { Dehydration } \\
20 \%\end{array}$ & 8 & 26.976 & 11.662 \\
\hline & & \multirow[t]{3}{*}{ Native } & Control & 3 & 25.740 & 3.942 \\
\hline & & & $\begin{array}{l}\text { Dehydration } \\
10 \%\end{array}$ & 6 & 42.666 & 10.665 \\
\hline & & & $\begin{array}{l}\text { Dehydration } \\
20 \%\end{array}$ & 6 & 47.023 & 9.724 \\
\hline & \multirow[t]{6}{*}{ Post } & \multirow[t]{3}{*}{ Invasive } & Control & 6 & 18.631 & 7.251 \\
\hline & & & $\begin{array}{l}\text { Dehydration } \\
10 \%\end{array}$ & 7 & 22.648 & 3.057 \\
\hline & & & $\begin{array}{l}\text { Dehydration } \\
20 \%\end{array}$ & 8 & 19.795 & 13.680 \\
\hline & & \multirow[t]{3}{*}{ Native } & Control & 3 & 30.553 & 4.809 \\
\hline & & & $\begin{array}{l}\text { Dehydration } \\
10 \%\end{array}$ & 6 & 32.110 & 13.029 \\
\hline & & & $\begin{array}{l}\text { Dehydration } \\
20 \%\end{array}$ & 6 & 25.945 & 9.977 \\
\hline \multirow[t]{12}{*}{ BKA (\%) } & \multirow[t]{6}{*}{ Pre } & \multirow[t]{3}{*}{ Invasive } & Control & 8 & 77.795 & 24.020 \\
\hline & & & $\begin{array}{l}\text { Dehydration } \\
10 \%\end{array}$ & 7 & 69.611 & 19.498 \\
\hline & & & $\begin{array}{l}\text { Dehydration } \\
20 \%\end{array}$ & 8 & 81.196 & 9.976 \\
\hline & & \multirow[t]{3}{*}{ Native } & Control & 5 & 10.968 & 14.873 \\
\hline & & & $\begin{array}{l}\text { Dehydration } \\
10 \%\end{array}$ & 6 & 16.458 & 10.134 \\
\hline & & & $\begin{array}{l}\text { Dehydration } \\
20 \%\end{array}$ & 6 & 22.223 & 7.410 \\
\hline & \multirow[t]{6}{*}{ Post } & \multirow[t]{3}{*}{ Invasive } & Control & 8 & 76.302 & 8.903 \\
\hline & & & $\begin{array}{l}\text { Dehydration } \\
10 \%\end{array}$ & 7 & 69.185 & 29.308 \\
\hline & & & $\begin{array}{l}\text { Dehydration } \\
20 \%\end{array}$ & 8 & 71.245 & 25.467 \\
\hline & & \multirow[t]{3}{*}{ Native } & Control & 5 & 24.516 & 13.573 \\
\hline & & & $\begin{array}{l}\text { Dehydration } \\
10 \%\end{array}$ & 6 & 18.085 & 10.120 \\
\hline & & & $\begin{array}{l}\text { Dehydration } \\
20 \%\end{array}$ & 6 & 20.833 & 11.053 \\
\hline \multirow[t]{12}{*}{ N:L Ratio } & \multirow[t]{6}{*}{ Pre } & \multirow[t]{3}{*}{ Invasive } & Control & 7 & 0.391 & 0.191 \\
\hline & & & $\begin{array}{l}\text { Dehydration } \\
10 \%\end{array}$ & 9 & 0.492 & 0.240 \\
\hline & & & $\begin{array}{l}\text { Dehydration } \\
20 \%\end{array}$ & 8 & 0.301 & 0.307 \\
\hline & & \multirow[t]{3}{*}{ Native } & Control & 5 & 0.480 & 0.204 \\
\hline & & & $\begin{array}{l}\text { Dehydration } \\
10 \%\end{array}$ & 6 & 0.748 & 0.310 \\
\hline & & & $\begin{array}{l}\text { Dehydration } \\
20 \%\end{array}$ & 6 & 0.546 & 0.202 \\
\hline & \multirow[t]{6}{*}{ Post } & \multirow[t]{3}{*}{ Invasive } & Control & 7 & 1.444 & 0.601 \\
\hline & & & $\begin{array}{l}\text { Dehydration } \\
10 \%\end{array}$ & 9 & 1.202 & 0.371 \\
\hline & & & $\begin{array}{l}\text { Dehydration } \\
20 \%\end{array}$ & 8 & 0.953 & 0.302 \\
\hline & & \multirow[t]{3}{*}{ Native } & Control & 5 & 1.094 & 0.249 \\
\hline & & & $\begin{array}{l}\text { Dehydration } \\
10 \%\end{array}$ & 6 & 1.253 & 0.632 \\
\hline & & & $\begin{array}{l}\text { Dehydration } \\
20 \%\end{array}$ & 6 & 0.665 & 0.275 \\
\hline \multirow{7}{*}{$\begin{array}{c}\text { CORT } \\
\text { (ng/ } \\
\text { mL) }\end{array}$} & \multirow[t]{6}{*}{ Pre } & \multirow[t]{3}{*}{ Invasive } & Control & 7 & 0.226 & 0.121 \\
\hline & & & $\begin{array}{l}\text { Dehydration } \\
10 \%\end{array}$ & 9 & 0.900 & 0.505 \\
\hline & & & $\begin{array}{l}\text { Dehydration } \\
20 \%\end{array}$ & 8 & 0.820 & 0.252 \\
\hline & & Native & Control & 4 & 0.368 & 0.315 \\
\hline & & & $\begin{array}{l}\text { Dehydration } \\
10 \%\end{array}$ & 6 & 0.841 & 0.329 \\
\hline & & & $\begin{array}{l}\text { Dehydration } \\
20 \%\end{array}$ & 6 & 1.037 & 0.385 \\
\hline & Post & Invasive & Control & 7 & 0.379 & 0.267 \\
\hline
\end{tabular}

Table 2 (continued)

\begin{tabular}{|c|c|c|c|c|c|c|}
\hline Variable & Restriction & Population & Group & $\mathrm{N}$ & Mean & SD \\
\hline & & \multirow{5}{*}{ Native } & $\begin{array}{l}\text { Dehydration } \\
10 \%\end{array}$ & 9 & 0.778 & 0.333 \\
\hline & & & $\begin{array}{l}\text { Dehydration } \\
20 \%\end{array}$ & 8 & 0.495 & 0.223 \\
\hline & & & Control & 4 & 0.535 & 0.034 \\
\hline & & & $\begin{array}{l}\text { Dehydration } \\
10 \%\end{array}$ & 6 & 0.593 & 0.306 \\
\hline & & & $\begin{array}{l}\text { Dehydration } \\
20 \%\end{array}$ & 6 & 0.737 & 0.275 \\
\hline
\end{tabular}

SD: Standard Deviation; HTC: Hematocrit; BKA: Bacterial Killing Ability; N:L Ratio: Neutrophil: Lymphocyte Ratio; CORT: Corticosterone plasma levels.

These organisms are exposed to new biotic and abiotic conditions, which exert novel selective pressures (Müller-Schärer et al., 2004; Carroll, 2008; White and Perkins, 2012; Brown et al., 2015), and favor the emergence of phenotypes that increase dispersal (Travis and Dytham, 2002; Shine et al., 2011; Brown et al., 2015; Courant et al., 2019) among other traits. Thus, it follows that diminished immune function could make invasive toads more susceptible to new pathogens, decreasing their survival and invasion success. Similar to our results, Brown et al. (2015) showed that offspring of invasive cane toads (Rhinella marina) in Australia have higher BKA, higher numbers of neutrophils and phagocytic activity on the invasion front when compared to offspring of toads from long-established populations bred under standard conditions. These results suggest genetically based shifts in immune response compromised by long-distance dispersal in free-ranging toads (Brown et al., 2015). Additionally, studies with shore crabs and birds show greater non-specific immune function of invasive individuals when compared to native ones (Keogh et al., 2017; Moller and Cassey, 2004). Still, according to Brown et al. (2015), the baseline levels of complement and neutrophils have been reinforced in cane toads on the invasion front, while the costs associated with its activation decreased. Thus, it is possible that invasive animals, such as $S$. gutturalis, tend to have increased constitutive immunity associated with increased surveillance. This would ensure a faster response to immunological challenges, reducing the scope of immune activation after infection and its costs associated with fever, anorexia, decreased locomotor activity, growth rates (Klasing and Korver, 1997; Spurlock, 1997; Lee and Klasing, 2004), and potentially dangerous systemic inflammatory response (Janeway Jr et al., 2001; Klein and Nelson, 1999; Lee and Klasing, 2004). It is unknown whether such responses are exaggerated in the invasive population as novel climates differ from the original, or if they are, at least in part, genetically determined in guttural toads. These hypotheses remain to be tested.

Blood leukocyte numbers and proportions have also been commonly used as indicators of physiological stress in vertebrates, including toads from the genus Rhinella (Davis et al., 2008; Campbell, 2015; Savage et al., 2016; Assis et al., 2015, 2017, 2019; Barsotti et al., 2017, 2019). In response to various stressors, including dehydration and malnutrition, the number of circulating neutrophils increases while the number of lymphocytes decreases, reflecting changes in leukocyte distribution and production (Davis et al., 2008; Savage et al., 2016; Barsotti et al., 2019). Moreover, increased N: L ratio has been shown to reflect more accurately chronic stress than increased glucocorticoid plasma levels (Davis et al., 2008; Swan and Hickman, 2014; Hickman, 2017). Thus, it is possible that anurans from the invading population in different environmental conditions and facing new challenges, may be more stressed, reflecting the neutrophilia and lymphopenia observed in our results.

Contrary to what we expected, toads from the invasive population show higher BKA both after dehydration and restriction protocols. Interestingly, the difference between populations regarding field BKA was maintained after captivity and all the experimental protocols. These results show that BKA's response was robust to exposure to acute stressors, at least within the period analyzed, suggesting an increase in 
Table 3

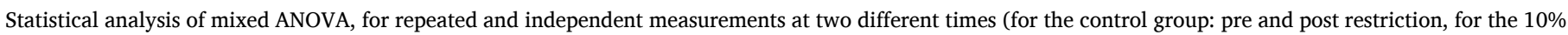
and $20 \%$ dehydration groups: dehydration and post-restriction), as well as interaction between treatment and group.

\begin{tabular}{|c|c|c|c|c|c|c|}
\hline Variable & Source & Type III SS & $\mathrm{DF}$ & MS & $\mathrm{F}$ & $P$ \\
\hline \multirow[t]{10}{*}{ HTC } & Intercept & 128.843 & 1 & 128.843 & 4768.653 & $<0.001$ \\
\hline & Restraint & 0.007 & 1 & 0.007 & 0.387 & 0.539 \\
\hline & Population & 0.217 & 1 & 0.217 & 8.018 & 0.008 \\
\hline & Group & 0.116 & 2 & 0.058 & 2.152 & 0.134 \\
\hline & Restraint*Population & 0.002 & 1 & 0.002 & 0.131 & 0.720 \\
\hline & Restraint*Group & 0.027 & 2 & 0.013 & 0.786 & 0.465 \\
\hline & Restraint*Population*Group & 0.069 & 2 & 0.034 & 1.999 & 0.154 \\
\hline & Population $*$ Group & 0.059 & 2 & 0.030 & 1.095 & 0.348 \\
\hline & Error (Restraint) & 0.497 & 29 & 0.017 & & \\
\hline & Error & 0.784 & 29 & 0.027 & & \\
\hline \multirow[t]{10}{*}{ BKA } & Intercept & $274,526.693$ & 1 & $274,526.693$ & 1321.536 & $<0.001$ \\
\hline & Restraint & 719.941 & 1 & 719.941 & 3.898 & 0.057 \\
\hline & Population & $29,540.097$ & 1 & $29,540.097$ & 142.202 & $<0.001$ \\
\hline & Group & 581.098 & 2 & 290.549 & 1.399 & 0.261 \\
\hline & Restraint*Population & 221.591 & 1 & 221.591 & 1.200 & 0.281 \\
\hline & Restraint*Group & 1.834 & 2 & 0.917 & 0.005 & 0.995 \\
\hline & Restraint*Population ${ }^{*}$ Group & 305.449 & 2 & 152.724 & 0.827 & 0.446 \\
\hline & Population*Group & 1041.507 & 2 & 520.754 & 2.507 & 0.096 \\
\hline & Error (Restraint) & 6279.394 & 34 & 184.688 & & \\
\hline & Error & 7062.926 & 34 & 207.733 & & \\
\hline \multirow[t]{10}{*}{ N:L Ratio } & Intercept & 56.426 & 1 & 56.426 & 1260.811 & $<0.001$ \\
\hline & Restraint & 2.196 & 1 & 2.196 & 87.737 & $<0.001$ \\
\hline & Population & 0.001 & 1 & 0.001 & 0.032 & 0.858 \\
\hline & Group & 0.424 & 2 & 0.212 & 4.739 & 0.016 \\
\hline & Restraint*Population & 0.253 & 1 & 0.253 & 10.117 & 0.003 \\
\hline & Restraint*Group & 0.143 & 2 & 0.072 & 2.866 & 0.071 \\
\hline & Restraint*Population ${ }^{*}$ Group & 0.053 & 2 & 0.026 & 1.054 & 0.360 \\
\hline & Population $*$ Group & 0.023 & 2 & 0.011 & 0.255 & 0.777 \\
\hline & Error (Restraint) & 0.826 & 33 & 0.025 & & \\
\hline & Error & 1.477 & 33 & 0.045 & & \\
\hline \multirow[t]{10}{*}{ CORT } & Intercept & 30.924 & 1 & 30.924 & 207.239 & $<0.001$ \\
\hline & Restraint & 0.237 & 1 & 0.237 & 5.013 & 0.032 \\
\hline & Population & 0.137 & 1 & 0.137 & 0.919 & 0.344 \\
\hline & Group & 2.369 & 2 & 1.185 & 7.939 & 0.001 \\
\hline & Restraint*Population & 0.004 & 1 & 0.004 & 0.086 & 0.770 \\
\hline & Restraint*Group & 0.679 & 2 & 0.340 & 7.182 & 0.003 \\
\hline & Restraint*Population*Group & 0.024 & 2 & 0.012 & 0.254 & 0.777 \\
\hline & Population $*$ Group & 0.472 & 2 & 0.236 & 1.580 & 0.221 \\
\hline & Error (Restraint) & 1.608 & 34 & 0.047 & & \\
\hline & Error & 5.073 & 34 & 0.149 & & \\
\hline
\end{tabular}

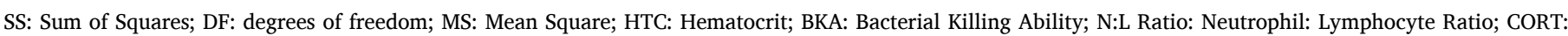
Corticosterone plasma levels.

constitutive immunity in the invasive population.

Moreover, dehydrating toads by $20 \%$ increased CORT and BKA, which may indicate an immunostimulatory effect of CORT. Accordingly, increased CORT along with different immune variables after submission to an acute stressor has been repeatedly observed in anurans (Assis et al., 2015, 2017, 2019; Titon et al., 2018; Titon et al., 2019; Barsotti et al., 2017, 2019). Dhabhar et al. (1996) showed that acute stress results in a rapid reduction in circulating leukocyte numbers associated with a redistribution of blood leukocytes to other organs, tending to increase the immune response in some body compartments. An acute response to stressors is also associated with increased antigen presentation, effector cell function, antibody production and cytokines expression (Dhabhar and McEwen, 1997). Additionally, in response to short-term stressors and acute increase in glucocorticoids, there is an increase in activity of the complement system (Dhabhar and McEwen, 1996, 1997; Dhabhar, 1998), which is also consistent with higher BKA response in dehydrated toads.

According to our predictions, dehydration activated the HPI axis culminating in increased CORT, mainly when toads were dehydrated by $20 \%$. This increase in CORT indicates that dehydration is a stressor for $S$. gutturalis, as has already been concluded for other vertebrate species (Arnhold et al., 2007; Cain and Lien, 1985; Moeller et al., 2017), including toads from genus Rhinella (Barsotti et al., 2019). Since CORT participates in the integrated physiological response of anurans to dehydration, due to its mineralotropic actions (Broillet et al., 1993;
Chen et al., 1998; Vera et al., 2017), it is possible that the increase of CORT observed in $S$. gutturalis may contribute to protection against possible deleterious effects caused by the loss of volume of extracellular fluid. Moreover, glucocorticoids potentiate the effects of angiotensin II (ANG II) mediating drinking behavior in mammals (Ganesan and Sumners, 1989; Sumners et al., 1991; Takei, 2000), and can similarly stimulate water seeking-behavior in anurans. Interestingly, hydrated individuals of $S$. gutturalis who had their CORT artificially increased, through transdermal application, showed an increase in water-seeking behavior (Madelaire et al., 2020). Considering that invasive toads tended to show lower hydration levels than native toads under field conditions, this higher efficiency in finding water due to increased CORT when dehydrated might favor the dispersal of the invasive Cape Town population.

Movement restriction represented a stressor for $S$. gutturalis, increasing the $\mathrm{N}$ : L ratio for both populations. Changes in leukocyte numbers and proportions in the blood are often used as indicators of infection and physiological stress in amphibians and other vertebrates (Assis et al., 2015, 2017, 2019; Barsotti et al., 2017, 2019; Davis et al., 2008; Campbell, 2015; Savage et al., 2016). Neutrophils and lymphocytes constitute the majority of blood leukocytes in amphibians (Savage et al., 2016) and the number of neutrophils increases and the lymphocyte decreases in the face of stressors, reflecting changes in leukocyte distribution and production (Davis et al., 2008; Savage et al., 2016). Assis et al. (2015) showed increased N: L ratio after restraint with 


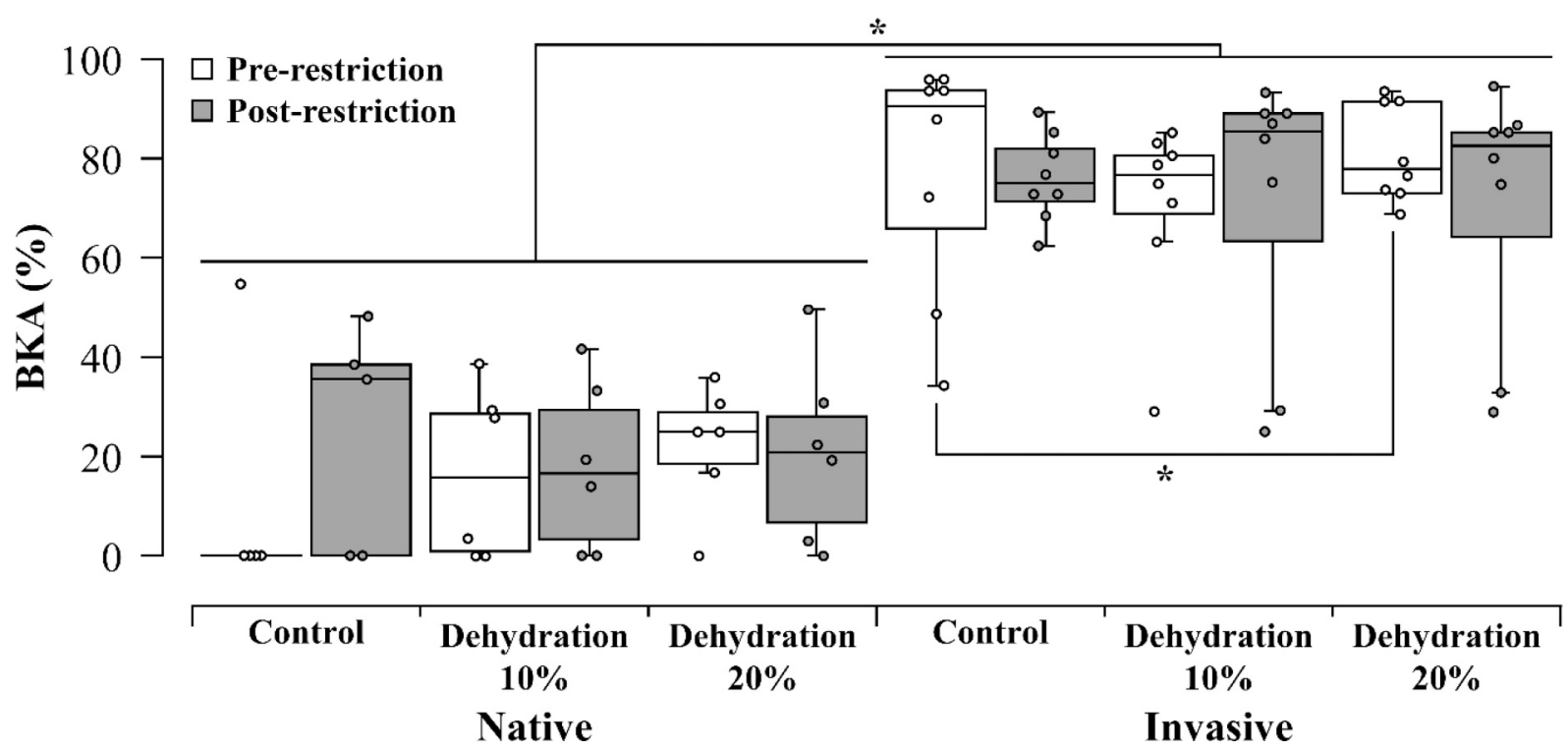

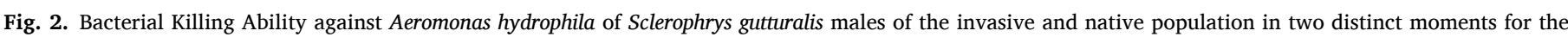

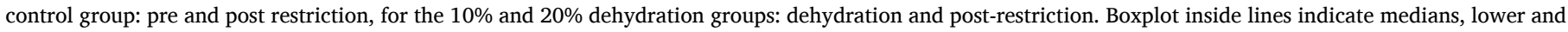

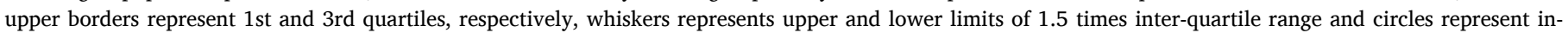
dividual data points. Asterisk $\left(^{*}\right)$ represents mean multiple comparisons with Bonferroni adjustment significant differences $(P \leq 0.05)$.

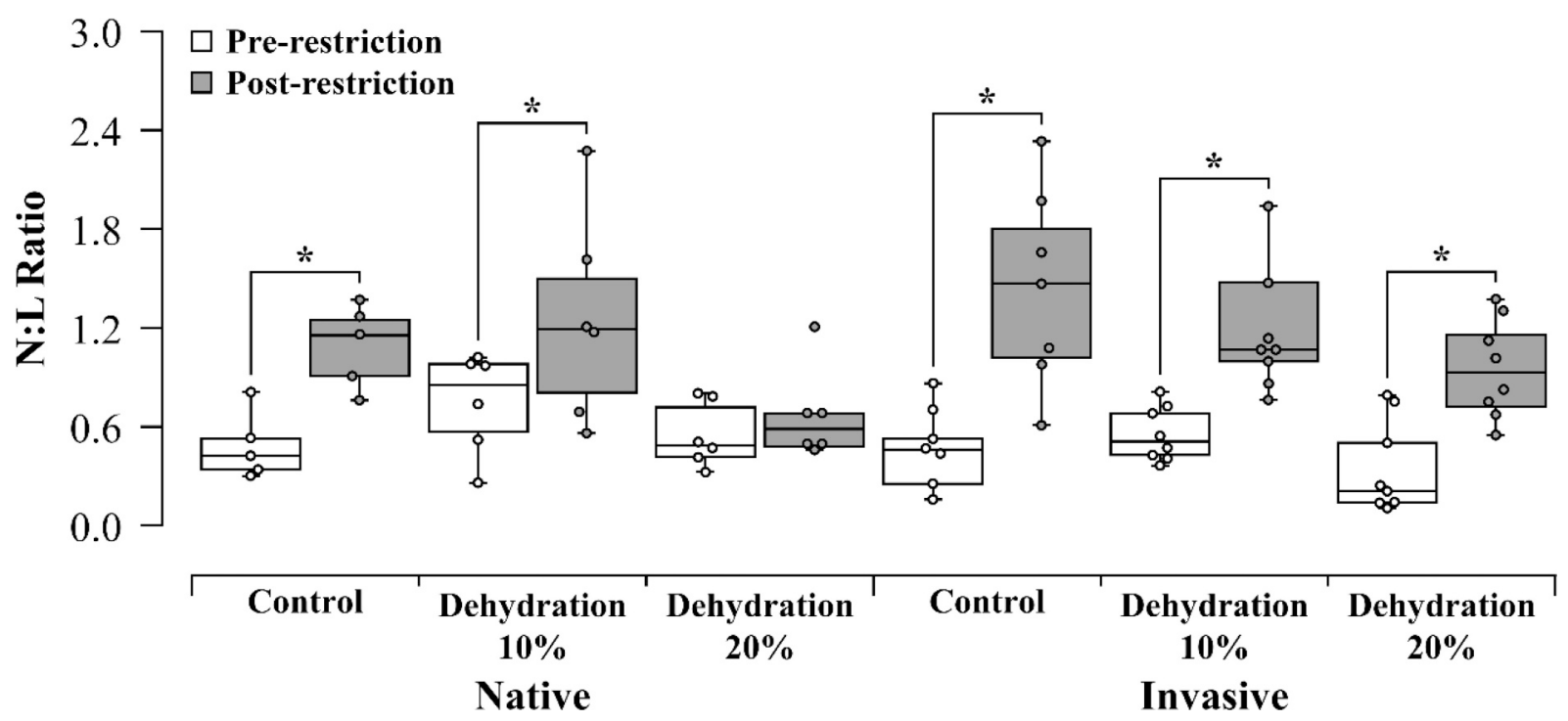

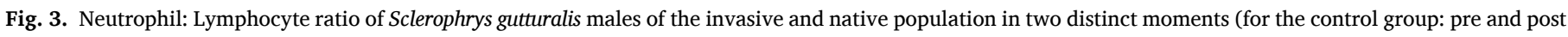

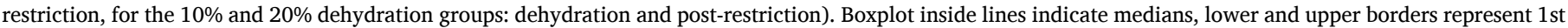

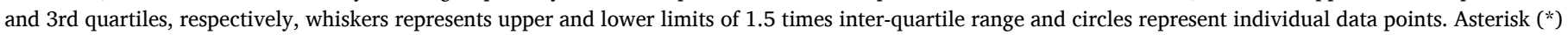
represents mean multiple comparisons with Bonferroni adjustment significant differences $(P \leq 0.05)$.

movement restriction in $R$. icterica, but not in individuals subjected to less stressful restraint without movement restriction. Additionally, Barsotti et al. (2019) showed that $R$. ornata subjected to $20 \%$ dehydration showed a more pronounced increase in $\mathrm{N}$ : $\mathrm{L}$ than those subjected to $10 \%$ dehydration.

CORT was not increased after $24 \mathrm{~h}$ of movement restriction in hydrated native and invasive toads, in contrast with previous observations on other anuran species (Assis et al., 2015, 2019; Barsotti et al., 2019). Given that the N: $\mathrm{L}$ ratio increased after movement restriction in these toads, it is probable that a peak of increased CORT in response to this treatment occurred earlier than the time at which the blood sample was collected. Moreover, it is interesting to observe that, both invasive and native toads that were dehydrated by $20 \%$ and posteriorly submitted to movement restriction, CORT values after movement restriction were lower than those measured after intense dehydration. Given that movement restriction was performed in damp cloth bags, toads may have rehydrated and reduced CORT during the period of movement restriction. Rehydration up to almost $100 \%$ has been previously observed in another toad (Rhinella ornata) under the same experimental conditions (Table 6- supp. file). Even so, these results suggest that movement restriction was not a stressor as intense as dehydration for this species. Likewise, intense dehydration is a more potent stressor than movement restriction in $R$. ornata (Barsotti et al., 2019), probably the only other anuran species from which there is data available on these two stressors.

In summary, invasive toads show lower standard field body mass, lower body index and tended to show lower hydration status in the field, which is consistent with life in the novel drier environmental conditions 


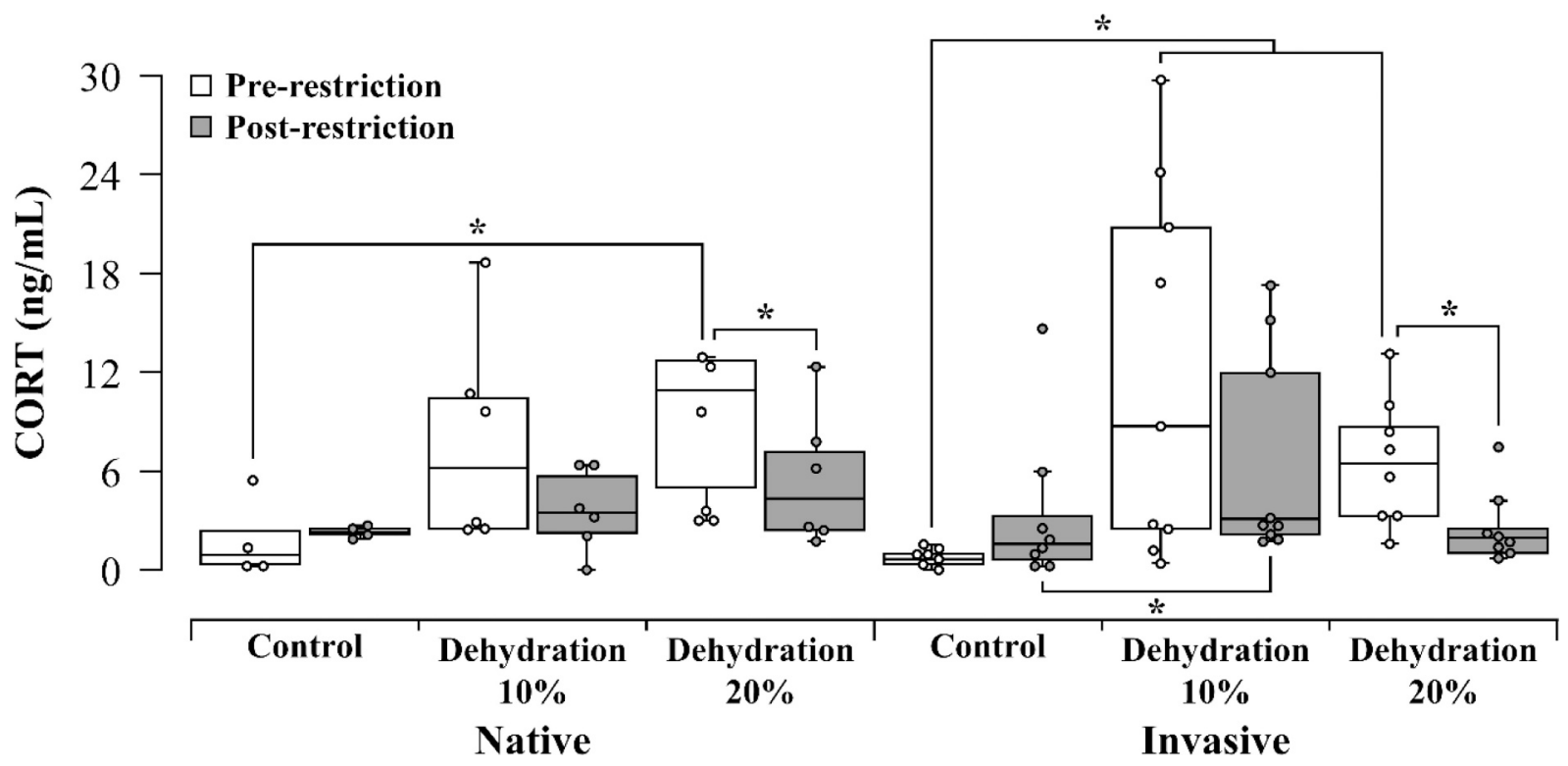

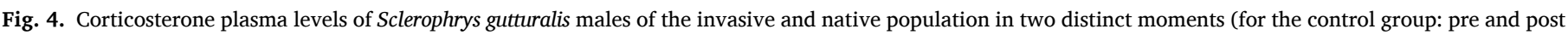

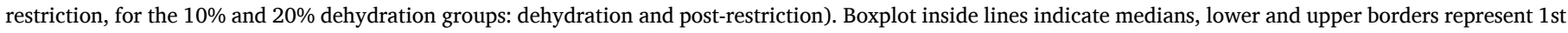

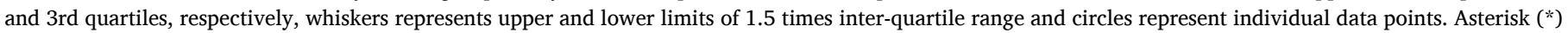
represents mean multiple comparisons with Bonferroni adjustment significant differences $(P \leq 0.05)$.

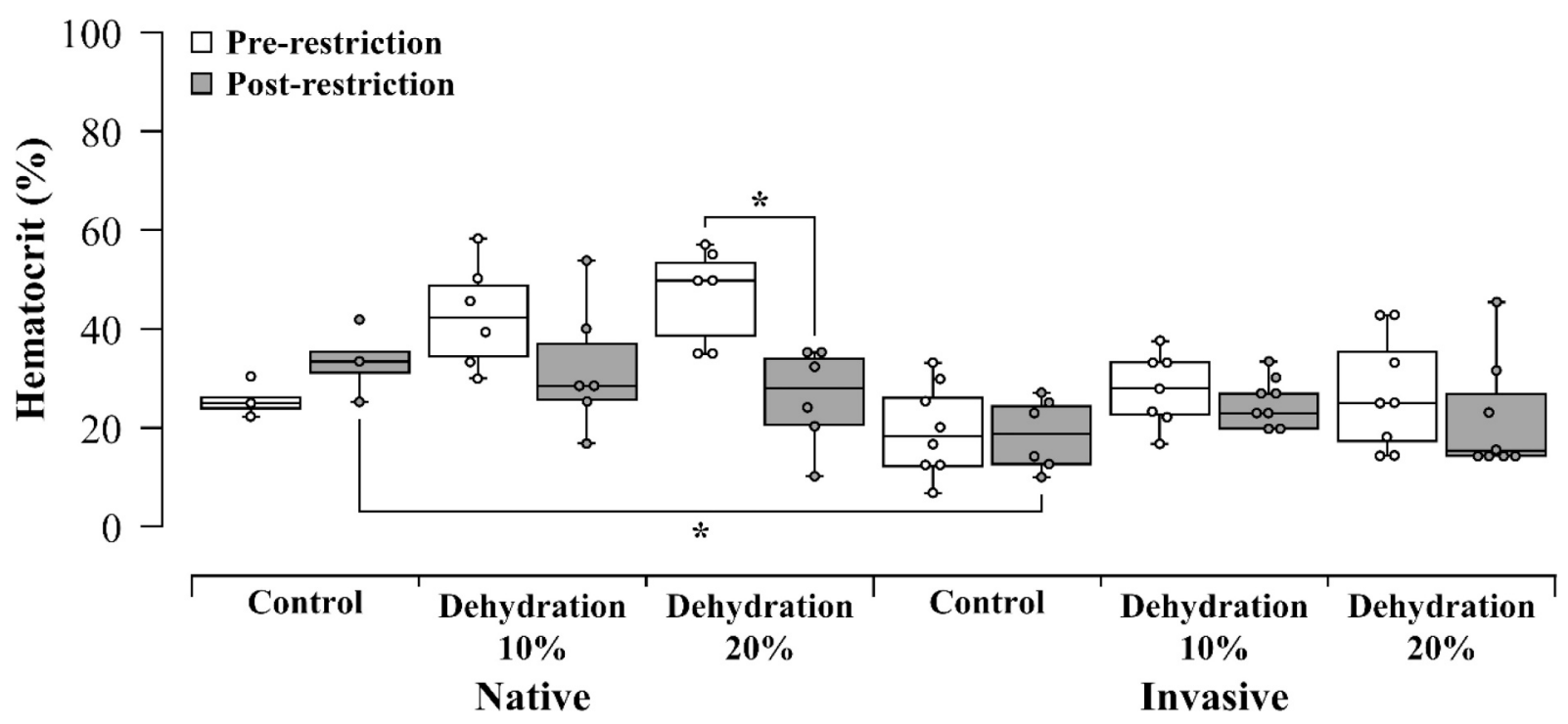

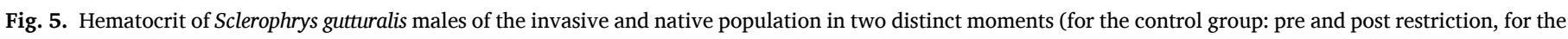

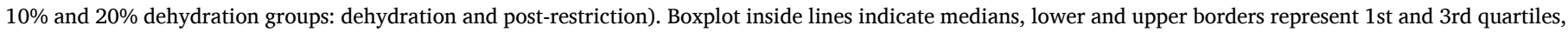

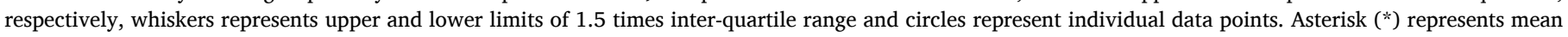
multiple comparisons with Bonferroni adjustment significant differences $(P \leq 0.05)$.

of Cape Town. Invading toads also showed higher $\mathrm{N}$ : L and BKA ratio in the field, compared to those from the native population, suggesting that invasive toads face stressful conditions and invest comparatively more in non-expensive components of their immune system. It is interesting to observe the persistence of inter-populational differences in BKA, even after submission to acute stress (dehydration and movement restriction). Although these traits have favored the permanence and dispersion of $S$. gutturalis in the invasive range, it is important to emphasize that we have investigated short-term phenotypic differences between these populations. An analysis of genetic diversity suggests this invasive population is not derived from founder effects (Telford et al., 2019). These differences might be, at least in part, due to plastic responses to current environmental differences during the breeding season
(Vimercati et al., 2019), or fast adaptive responses after 20 years of their introduction in Cape Town (Vimercati et al., 2018). Additional studies, including rearing individuals form both populations under common garden conditions, would be necessary to understand the causes of this phenotypic divergence.

\section{Funding}

This work was supported by Fundação de Amparo à Pesquisa do Estado de São Paulo (FAPESP) through a grant for F.R.G (2014/163207), PhD scholarship to A.M.G.B (2018/23661-6) and postdoctoral fellowship awarded to C.B.M. (2018/00406-0). F.R. Gomes is a research fellow from the Brazilian Conselho Nacional de Desenvolvimento 
Científico e Tecnológico (CNPq) \#302308/2016-4. J. Measey is chief researcher at the Centre for Invasion Biology (C.I.B) based in the Department of Botany and Zoology at Stellenbosch University.

\section{Declaration of Competing Interest}

The authors declare no competing or financial interests.

\section{Acknowledgements}

We would like to thank Professor Hannes van Wyk for allowing the use of his laboratory and equipment. This study was supported by the Fundação de Amparo à Pesquisa do Estado de São Paulo (FAPESP) FRG (2013/00900-1 and 2014/16320-7), AMGB (2018/23661-6) and CBM (2018/00406-0). JM and CW would like to thank the DSI-NRF Centre of Excellence for Invasion Biology and Stellenbosch University.

\section{Appendix A. Supplementary data}

Supplementary data to this article can be found online at https://doi. org/10.1016/j.cbpa.2020.110870.

\section{References}

Altieri, A.H., Wesenbeeck, B.K.V., Bertness, M.D., Silliman, B.R., 2010. Facilitation cascade drives positive relationship between native biodiversity and invasion success. Ecology. 91, 1269-1275.

Arnhold, M.M., Wotus, C., Engeland, W.C., 2007. Differential regulation of parvocellular neuronal activity in the paraventricular nucleus of the hypothalamus following single vs. repeated episodes of water restriction-induced drinking. Exp. Neurol. 206, 126-136.

Assis, V.R., Titon, S.C.M., Barsotti, A.M.G., Spira, B., Gomes, F.R., 2013. Antimicrobial capacity of plasma from anurans of the Atlantic Forest. South Am. J. Herpetol. 8, 155-160.

Assis, V.R., Titon, S.C.M., Barsotti, A.M.G., Titon Jr., B., Gomes, F.R., 2015. Effects of acute restraint stress, prolonged captivity stress and transdermal corticosterone application on immunocompetence and plasma levels of corticosterone on the cururu toad (Rhinella icterica). PLoS One 10, 1-21.

Assis, V.R., Titon, S.C.M., Queiroz-Hazarbassanov, N.G.T., Massoco, C.O., Gomes, F.R., 2017. Corticosterone transdermal application in toads (Rhinella icterica): effects on cellular and humoral immunity and steroid plasma levels. J. Exp. Zool. A. Ecol. Integr. Physiol. 327, 200-213.

Assis, V.R., Titon, S.C.M., Gomes, F.R., 2019. Acute stress, steroid plasma levels, and innate immunity in Brazilian toads. Gen. Comp. Endocrinol. 273, 86-97.

Barsotti, A.M.G., de Assis, V.R., Titon, S.C.M., Junior, B.T., da Silva Ferreira, Z.F., Gomes, F.R., 2017. ACTH modulation on corticosterone, melatonin, testosterone and innate immune response in the tree frog Hypsiboas faber. Comp. Biochem. Physiol Part A 204, 177-184.

Barsotti, A.M.G., Titon Junior, B., Titon, S.C.M., Gomes, F.R., 2019. Dehydration as a stressor in toads (Rhinella ornata). J. Exp. Zool. Part A 331, 168-174.

Bonier, F., Martin, P.R., Moore, I.T., Wingfield, J.C., 2009. Do baseline glucocorticoids predict fitness? Trends Ecol. Evol. 24, 634-642.

Broillet, M.C., Berger, A., Horisberger, J.D., 1993. Early effects of aldosterone on the basolateral potassium conductance of A6 cells. Pflugers Arch. 424, 91-93.

Brown, G.P., Shilton, C., Phillips, B.L., Shine, R., 2007. Invasion, stress, and spinal arthritis in cane toads. Proc. Natl. Acad. Sci. 104, 17698-17700.

Brown, G.P., Kelehear, C., Shine, R., 2011. Effects of seasonal aridity on the ecology and behaviour of invasive cane toads in the Australian wet-dry tropics. Funct. Ecol. 25, 1339-1347.

Brown, G.P., Phillips, B.L., Dubey, S., Shine, R., 2015. Invader immunology: invasion history alters immune system function in cane toads (Rhinella marina) in tropical Australia. Ecol. Lett. 18, 57-65.

Brown, G.P., Shine, R., 2014. Immune response varies with rate of dispersal in invasive cane toads (Rhinella marina). PLoS One 9, 1-11.

Cain, J.R., Lien, R.J., 1985. A model for drought inhibition of bobwhite quail (Colinus virginianus) reproductive systems. Comp. Biochem. Physiol. A Mol. Physiol. 82, 925-930.

Campbell, T., 2015. Exotic Animal Hematology and Cytology. John Wiley \& Sons.

Campbell, T.W., 2012. Hematology of amphibians. In: Trall, M.A. (Ed.), Veterinary Hematology and Clinical Chemistry. John Wiley \& Sons, Inc., Oxford, UK.

Carroll, S.P., 2008. Facing change: forms and foundations of contemporary adaptation to biotic invasions. Mol. Ecol. 17, 361-372.

Chen, S.Y., Wang, J., Liu, W., Pearce, D., 1998. Aldosterone responsiveness of A6 cells is restored by cloned rat mineralocorticoid receptor. Am. J. Physiol. Cell Physiol. 274, $39-46$.

Chown, S.L., Hoffmann, A.A., Kristensen, T.N., Angilletta Jr., M.J., Stenseth, N.C., Pertoldi, C., 2010. Adapting to climate change: a perspective from evolutionary physiology. Clim. Res. 43, 3-15.
Cohen, A.A., Martin, L.B., Wingfield, J.C., McWilliams, S.R., Dunne, J.A., 2012. Physiological regulatory networks: ecological roles and evolutionary constraints. Trends Ecol. Evol. 27, 428-435.

Courant, J., Secondi, J., Guillemet, L., Vollette, E., Herrel, A., 2019. Rapid changes in dispersal on a small spatial scale at the range edge of an expanding population. Evol. Ecol. 33, 599-612.

Davies, S.J., Bell, J.A., Impson, D., Mabin, C., Meyer, M., Rhoda, C., Stafford, L., Stephens, K., Tafeni, M., Turner, A.A., Van Wilgen, N.J., Wilson, J.R.U., Wood, J., Measey, J., 2020. Coordinating invasive alien species management in a biodiversity hotspot: the CAPE Invasive Alien Animals Working Group. Bothalia 50 (1), a10.

Davis, A.K., Maney, D.L., Maerz, J.C., 2008. The use of leukocyte profiles to measure stress in vertebrates: a review for ecologists. Funct. Ecol. 22, 760-772.

Dhabhar, F.S., 1998. Stress-induced enhancement of cell-mediated immunity a. Ann. N. Y. Acad. Sci. 840, 359-372.

Dhabhar, F.S., 2014. Effects of stress on immune function: the good, the bad, and the beautiful. Immunol. Res. 58, 193-210.

Dhabhar, F.S., McEwen, B.S., 1996. Stress-induced enhancement of antigen-specific cellmediated immunity. J. Immunol. 156, 2608-2615.

Dhabhar, F.S., McEwen, B.S., 1997. Acute stress enhances while chronic stress suppresses cell-mediated immunityin vivo: a potential role for leukocyte trafficking. Brain Behav. Immun. 11, 286-306.

Dhabhar, F.S., Miller, A.H., Stein, M., McEwen, B.S., Spencer, R.L., 1994. Diurnal and acute stress-induced changes in distribution of peripheral blood leukocyte subpopulations. Brain Behav. Immun. 8, 66-79.

Dhabhar, F.S., Miller, A.H., McEwen, B.S., Spencer, R.L., 1995. Effects of stress on immune cell distribution. Dynamics and hormonal mechanisms. J. Immunol. 154, $5511-5527$.

Dhabhar, F.S., Miller, A.H., McEwen, B.S., Spencer, R.L., 1996. Stress-induced changes in blood leukocyte distribution. Role of adrenal steroid hormones. J. Immunol. 157, 1638-1644.

Ganesan, R., Sumners, C., 1989. Glucocorticoids potentiate the dipsogenic action of angiotensin II. Brain Res. 499, 121-130.

Hickman, D., 2017. Evaluation of the neutrophil:lymphocyte ratio as an indicator of chronic distress in the laboratory mouse. Lab. Anim. 46, 303-307.

Hillman, S.S., 2018. Anuran amphibians as comparative models for understanding extreme dehydration tolerance: a unique negative feedback lymphatic mechanism for blood volume regulation. Am. J. Physiol. Regul. Integr. Comp. 315, 790-798.

Janeway Jr., C.A., Travers, P., Walport, M., Shlomchik, M.J., 2001. The complement system and innate immunity. In: Immunobiology: The Immune System in Health and Disease, 5th edn. Garland Science.

Jessop, T.S., Letnic, M., Webb, J.K., Dempster, T., 2013. Adrenocortical stress responses influence an invasive vertebrate's fitness in an extreme environment. Proc. R. Soc. B Biol. Sci. 280, 1-9.

Keogh, C.L., Miura, O., Nishimura, T., Byers, J.E., 2017. The double edge to parasite escape: invasive host is less infected but more infectable. Ecology 98, 2241-2247.

Klasing, K.C., Korver, D.R., 1997. Leukocytic cytokines regulate growth rate and composition following activation of the immune system. J. Anim. Sci. 75, 58-67.

Klein, S.L., Nelson, R.J., 1999. Activation of the immune-endocrine system with lipopolysaccharide reduces affiliative behaviors in voles. Behav. Neurosci. 113, 1042-1048.

Kosmala, G., Christian, K., Brown, G., Shine, R., 2017. Locomotor performance of cane toads differs between native-range and invasive populations. R. Soc. Open Sci. 4, $1-11$.

Kosmala, G.K., Brown, G.P., Shine, R., 2020. Thin-skinned invaders: geographic variation in the structure of the skin among populations of cane toads (Rhinella marina). Biol. J. Linn. Soc. XX, 1-11.

Lee, C.E., 2002. Evolutionary genetics of invasive species. Trends Ecol. Evol. 17, 386-391.

Lee, K.A., Klasing, K.C., 2004. A role for immunology in invasion biology. Trends Ecol. Evol. 19, 523-529.

Llewellyn, D., Thompson, M.B., Brown, G.P., Phillips, B.L., Shine, R., 2012. Reduced investment in immune function in invasion-front populations of the cane toad (Rhinella marina) in Australia. Biol. Invasions 14, 999-1008.

Madelaire, C.B., Sokolova, I., Gomes, F.R., 2017. Seasonal patterns of variation in steroid plasma levels and immune parameters in anurans from Brazilian semiarid area. Physiol. Biochem. Zool. 90, 415-433.

Madelaire, C.B., de Oliveira Cassettari, B., Gomes, F.R., 2019. Immunomodulation by testosterone and corticosterone in toads: experimental evidences from transdermal application. Gen. Comp. Endocrinol. 273, 227-235.

Madelaire, C.B., Barsotti, A.M., Wagener, C., Sugano, Y.Y.V., Baxter-Gilbert, J., Gomes, F. R., Measey, J., 2020. Challenges of dehydration result in a behavioral shift in invasive toads. Behav. Ecol. Sociobiol. 74, 1-15.

Martin, B.L., 2009. Stress and immunity in wild vertebrates: timing is everything. Gen. Comp. Endocrinol. 163, 70-76.

Martin, L.B., Liebl, A.L., Trotter, J.H., Richards, C.L., McCoy, K., McCoy, M.W., 2011. Integrator networks: illuminating the black box linking genotype and phenotype. Intgr. Comp. Biol. 51, 514-527.

Measey, J., Davies, S., Vimercati, G., Rebelo, A., Schmidt, W., Turner, A.A., 2017 Invasive amphibians in southern Africa: a review of invasion pathways. BothaliaAfrican Biodiversity Conservation 47, 1-12.

Measey, J., Hui, C., Somers, M.J., 2020. Terrestrial vertebrate invasions in South Africa. In: Biological Invasions in South Africa. Springer, Cham.

Moeller, K.T., Butler, M.W., DeNardo, D.F., 2013. The effect of hydration state and energy balance on innate immunity of a desert reptile. Front. Zool. 10, 23. 
Moeller, K.T., Demare, G., Davies, S., DeNardo, D.F., 2017. Dehydration enhances multiple physiological defense mechanisms in a desert lizard, Heloderma suspectum. J. Exp. Biol. 220, 2166-2174.

Moller, A.P., Cassey, P., 2004. On the relationship between T-cell mediated immunity in bird species and the establishment success of introduced populations. J. Anim. Ecol. 73, 1035-1042.

Mooney, H.A., Hobbs, R.J., 2000. Invasive Species in a Changing World. Island Press, Washington, DC.

Moore, F.R., Gatten Jr., R.E., 1989. Locomotor performance of hydrated, dehydrated, and osmotically stressed anuran amphibians. Herpetologica 45, 101-110.

Moretti, E.H., Titon, S.C.M., Junior, B.T., Marques, F.S., Gomes, F.R., 2019. Thermal sensitivity of innate immune response in three species of Rhinella toads. Comp. Biochem. Physiol. A Mol. Integr. Physiol. 237, 1-9.

Müller-Schärer, H., Schaffner, U., Steinger, T., 2004. Evolution in invasive plants: implications for biological control. Trends Ecol. Evol. 19, 417-422.

Pimentel, D., 2014. Biological Invasions: Economic and Environmental Costs of Alien Plant, Animal, and Microbe Species. CRC Press, Boca Raton, FL.

Preest, M.R., Pough, F.H., 1989. Interaction of temperature and hydration on locomotion of toads. Funct. Ecol. 3, 693-699.

Preest, M.R., Brust, D.G., Wygoda, M.L., 1992. Cutaneous water loss and the effects of temperature and hydration state on aerobic metabolism of canyon treefrogs, Hyla arenicolor. Herpetologica 48, 210-219.

Reznick, D.N., Ghalambor, C.K., 2001. The population ecology of contemporary adaptations: what empirical studies reveal about the conditions that promote adaptive evolution. Genetica 112, 183-198.

Rich, E.L., Romero, L.M., 2005. Exposure to chronic stress downregulates corticosterone responses to acute stressors. Am. J. Physiol. Regul. Integr. Comp. Physiol. 288, 1628-1636.

Romero, L.M., Reed, J.M., 2005. Collecting baseline corticosterone samples in the field: is under 3 min good enough? Comp. Biochem. Physiol. A Mol. Integr. Physiol. 140, 73-79.

Romero, L.M., Wingfield, J.C., 2001. Regulation of the hypothalamic-pituitary-adrenal axis in free-living pigeons. J. Comp. Physiol. B. 171, 231-235.

Romero, L.M., Wingfield, J.C., 2015. Tempests, Poxes, Predators, and People: Stress in Wild Animals and How they Cope. Oxford University Press.

Roznik, E.A., Rodriguez-Barbosa, C.A., Johnson, S.A., 2018. Hydric balance and locomotor performance of native and invasive frogs. Front. Ecol. Evol. 6, 159.

Ruibal, R., 1962. The adaptive value of bladder water in the toad Bufo cognatus. Physiol. Zool. 35, 218-223.

Sapolsky, R.M., 2002. Endocrinology of the stress-response. In: Becker, J.B., Breedlove, S. M., Crews, D., McCarthy, M.M. (Eds.), Behavioral Endocrinology. MIT Press, pp. 409-450.

Sapolsky, R.M., Romero, L.M., Munck, A.U., 2000. How do glucocorticoids influence stress responses? Integrating permissive, suppressive, stimulatory, and preparative actions. Endocr. Rev. 21, 55-89.

Savage, A.E., Terrell, K.A., Gratwicke, B., Mattheus, N.M., Augustine, L., Fleischer, R.C., 2016. Reduced immune function predicts disease susceptibility in frogs infected with a deadly fungal pathogen. Conserv. Physiol. 4, 1-11.

Sax, D.F., Stachowicz, J.J., Brown, J.H., Bruno, J.F., Dawson, M.N., Gaines, S.D., Grosberg, R.K., Hastings, A., Holt, R.D., Mayfield, M.M., O'Connor, M.I., Rice, W.R. 2007. Ecological and evolutionary insights from species invasions. Trends Ecol. Evol. 22, 465-471.

Seebacher, F., Franklin, C.E., 2011. Physiology of invasion: cane toads are constrained by thermal effects on physiological mechanisms that support locomotor performance. J. Exp. Biol. 214, 1437-1444.

Shine, R., Brown, G.P., Phillips, B.L., 2011. An evolutionary process that assembles phenotypes through space rather than through time. Proc. Natl. Acad. Sci. 108, 5708-5711.

Spurlock, M.E., 1997. Regulation of metabolism and growth during growth challenge: an overview of cytokine function. J. Anim. Sci. 75, 1773-1783.

Sterberg, E.M., 2006. Neural regulation of innate immunity: a coordinated nonspecific host response to pathogens. Nat. Rev. Immunol. 6, 318-328.
Strauss, S.Y., Lau, J.A., Carroll, S.P., 2006. Evolutionary responses of natives to introduced species: what do introductions tell us about natural communities? Ecol. Lett. 9, 357-374.

Sumners, C., Gault, T.R., Fregly, M.J., 1991. Potentiation of angiotensin II-induced drinking by glucocorticoids is a specific glucocorticoid Type II receptor (GR)mediated event. Brain Res. 552, 283-290.

Swan, M., Hickman, D., 2014. Evaluation of the neutrophil-lymphocyte ratio as a measure of distress in rats. Lab. Anim. 43, 276-282.

Takei, Y., 2000. Comparative physiology of body fluid regulation in vertebrates with special reference to thirst regulation. Jpn. J. Physiol. 50, 171-186.

Telford, N.S., Channing, A., Measey, J., 2019. Origin of invasive populations of the Guttural Toad (Sclerophrys gutturalis) on Reunion and Mauritius Islands and in Constantia, South Africa. Herpetol. Conserv. Biol. 14, 380-392.

Tingley, R., Shine, R., 2011. Desiccation risk drives the spatial ecology of an invasive anuran (Rhinella marina) in the Australian semi-desert. PLoS One 6 (10), e25979.

Tingley, R., Greenlees, M.J., Shine, R., 2012. Hydric balance and locomotor performance of an anuran (Rhinella marina) invading the Australian arid zone. Oikos 121, 1959-1965.

Titon Jr., B., Gomes, F.R., 2017. Associations of water balance and thermal sensitivity of toads with macroclimatic characteristics of geographical distribution. Comp. Biochem. Physiol. A Mol. Integr. Physiol. 208, 54-60.

Titon, S.C.M., Junior, B.T., Assis, V.R., Kinker, G.S., Fernandes, P.A.C.M., Gomes, F.R., 2018. Interplay among steroids, body condition and immunity in response to longterm captivity in toads. Sci. Rep. 8, 1-13.

Titon, S.C.M., Titon Jr, B., Barsotti, A.M.G., Gomes, F.R., Assis, V.R., 2019. Time-related immunomodulation by stressors and corticosterone transdermal application in toads. Plos One 14, 1-18. https://doi.org/10.1371/journal.pone.0222856.

Toledo, R.C., Jared, C., 1993. Cutaneous adaptations to water balance in amphibians. Comp. Biochem. Physiol. A Mol. Integr. Physiol. 105, 593-608.

Torchin, M.E., Lafferty, K.D., Dobson, A.P., McKenzie, V.J., Kuris, A.M., 2003. Introduced species and their missing parasites. Nature 421, 628-630.

Tracy, C.R., Tixier, T., Le Nöene, C., Christian, K.A., 2014. Field hydration state varies among tropical frog species with different habitat use. Physiol. Biochem. Zool. 87, 197-202.

Travis, J.M., Dytham, C., 2002. Dispersal evolution during invasions. Evol. Ecol. Res. 4, 1119-1129.

Tylan, C., Camacho, K., French, S.S., Graham, S.P., Herra, M.W., Jones, J., McCormick, G.L., O’Briena, M.A., Tennessen, J.B., Thawley, C.J., Webb, A., Langkilde, T., 2020. Obtaining plasma to measure baseline corticosterone concentrations in reptiles: how quick is quick enough? Gen. Comp. Endocrinol. 287, 113324.

Vera, F., Zenuto, R., Antenucci, C.D., 2017. Expanding the actions of cortisol and corticosterone in wild vertebrates: a necessary step to overcome the emerging challenges. Gen. Comp. Endocrinol. 246, 337-353.

Vimercati, G., Davies, S.J., Hui, C., Measey, J., 2017. Does restricted access limit management of invasive urban frogs? Biol. Invasions 19, 3659-3674.

Vimercati, G., Davies, S.J., Measey, J., 2018. Rapid adaptive response to a mediterranean environment reduces phenotypic mismatch in a recent amphibian invader. J. Exp. Biol. 221, 1-9.

Vimercati, G., Davies, S., Measey, J., 2019. Invasive toads adopt marked capital breeding when introduced to a cooler, more seasonal environment. Biol. J. Linn. Soc. 128, 657-671.

White, T.A., Perkins, S.E., 2012. The ecoimmunology of invasive species. Funct. Ecol. 26, 1313-1323.

Wingfield, J.C., 2008. Comparative endocrinology, environment and global change. Gen. Comp. Endocrinol. 157, 207-216.

Wingfield, J.C., Hunt, K., Breuner, C., Dunlap, K., Fowler, G.S., Freed, L., Lepson, J.A., 1997. Environmental stress, field endocrinology, and conservation biology. In: Buchholz, R., Clemmons, J.R. (Eds.), Behavioral Approaches to Conservation in the Wild. Cambridge University Press, Cambridge UK, pp. 95-131. 